\title{
Optimization of biotechnological processes in the production of apple juice
}

\author{
Natalia Droficheva \\ Federal State Budget Scientific Institution «North Caucasian Federal Scientific Center of \\ Horticulture, Viticulture, Wine-making», 39 str. 40 Let Pobedy, Krasnodar, 350901, Russia
}

\begin{abstract}
When obtaining apple juice, the issue of optimizing biotechnological processes is acute. The use of enzyme preparations of different specifics of the action allows you to choose the optimal parameters of the technological process and select the drug taking into account the purpose ofuse. The influence of enzyme preparations: Trinoline 4000, Trinolin DF, Fructocyme P6-L, Lafaze on the yield of juice and biologically active substances in the processing of fruit raw materials was studied. An enzyme preparation that maximizes the yield of apple juice has been isolated. Their effect on the extraction of biologically active substances has been determined.
\end{abstract}

\section{Introduction}

Apples are the main, most popular raw materials in Russia, from which almost any type of canned products of high quality are produced $[1,2]$. In the structure of nutrition of any person should be present fruits, which are the main sources of biologically active substances, fiber, vitamins, pectins, minerals, etc. Fruit juices are characterized by a high content of biologically active substances. Many literary sources indicate that apple raw materials contain a significant amount of pectin substances, which, in addition to a positive effect on the human body, also have a negative effect on production - reduce the yield of juice and increase waste. In this regard, at processing enterprises, an important task is to create wastefree technologies for the production of juices. In European countries, enzyme preparations of various actions are used to extract juice from fruit raw materials [2, 3, 4]. The main goal of optimizing biotechnological processes in the processing of fruit raw materials is the use of a complex of enzymes that contribute to the breakdown of polysaccharides of fruit tissue. Pectins refer to carbohydrates, for the extraction and degradation of which, the use of complex biotechnological methods of exposure is required $[5,6]$. The use of pectolytic enzyme preparations leads to the rupture of a long molecule of pectin and an increase in the yield of juice and filtration rate. When fermenting raw materials, hydrolysis of rectilinear sections of the pectin molecule is necessary, for which preparations with high polygalacturonase activity are used. The use of pectolytic enzyme preparations leads to the rupture of a long molecule of pectin and an increase in the yield of juice and filtration rate. Enzyme preparations of the same action are used not only to optimize technological processes, but also for the extraction of coloring substances. When fermenting raw materials, 
hydrolysis of rectilinear sections of the pectin molecule is necessary, for which preparations with high polygalacturonase activity are used [7, 8].

Also, in the production of juices, amylolytic enzymes are used, which contribute to improving the appearance of products and durability during storage, due to the splitting of starch into sugars $[2,8]$. The main advantages of the use of enzymes in the development of new food technologies and biotechnological processes are:

1. Maximum reliability of the results and specificity of the action of enzymes. The effect of the use of which is based on the complementarity of the spatial configuration of the active center and substrate [9].

2. Simple and fast measurement procedure, eliminating the use of expensive equipment.

3. High sensitivity of the method and reproducibility of the results. Extensive application of enzymes: quality control of finished products, production control of raw materials, analysis of the composition of the food product, assessment of hygienic status [9, 10].

Enzyme preparations (APs) must meet the requirements of food enterprises to obtain a specific product (according to the type of catalyzed reaction and flow conditions).

\section{Materials and Methods}

Objects of research: fruits of apples (Kuban crimson variety), grown in the conditions of the south of Russia; enzyme preparations (Trinoline 4000, Trinolin DF, Fructocyme P6-L, Lafaze); apple juice.

All laboratory tests were performed on high-tech equipment of the Central Control Center (Center of Collective Use) in the following areas: physiological, biochemical and microbiological studies; food safety according to generally accepted methods and GOSTs.

When studying the qualitative indicators of apple fruits (Kubancrimson variety) and juice, they determined: soluble dry substances - according to GOST ISO 2173-2013 with a digital refractometer PAL-3(ATAGO); general sugars - by photometric method on the photoelectrocolorimeter CK-3-01 according to GOST 8756.13-87; fractional composition of sugars (D-glucoseand D-fructose and sucrose)- according to GOST R 51440-99; vitamin C iodometric method with potassium iodate; vitamin $\mathbf{P}$ - colorimetric method in the modification of L. And. Vigorova with vanillin reagent; pectin substances - carbazole method in modification E. In. Sapozhnikova (1965). aromatic substances - on the gas chromatograph "Crystal 2000M". Statistical processing of the results was carried out using the program Microsoft Office Excel.

\section{Results and Discussion}

The fruits of apples contain a significant proportion of fiber and hemicellulose, which can serve as a reserve for increasing nutritional value, due to partial enzymatic hydrolysis of nonstarchy polysaccharides. Processing of apple raw materials with enzymes allows to increase the content of other biologically active components, including extractive substances. For the production of apple juice with pulp, most processing plants use mechanical grinding with additional heat treatment, as a result of which acid hydrolysis of protopectin occurs $[10,11$, 12]. However, it is worth noting that such processes significantly reduce the nutritional value and worsen the organoleptic parameters of the product (insufficiently finely crushed pulp, inhomogeneous and exfoliated during storage). Therefore, the use of enzyme preparations (APs) for the treatment of apple raw materials, the effect of which is to reduce the viscosity of the juice due to the splitting of a significant part of pectin substances, is rational $[9,12]$. 
For experiments, APs with pectolytic and polygalacturonase activities were selected. Enzyme preparations were introduced in equal doses. All treatments were carried out in optimal conditions for the action of enzymes recommended by the manufacturer "Eurotrade".

The effectiveness of the effect of enzymes on the juice yield has been established. The control sample was apple juice obtained under the same conditions, but without the introduction of APs (Fig. 1).

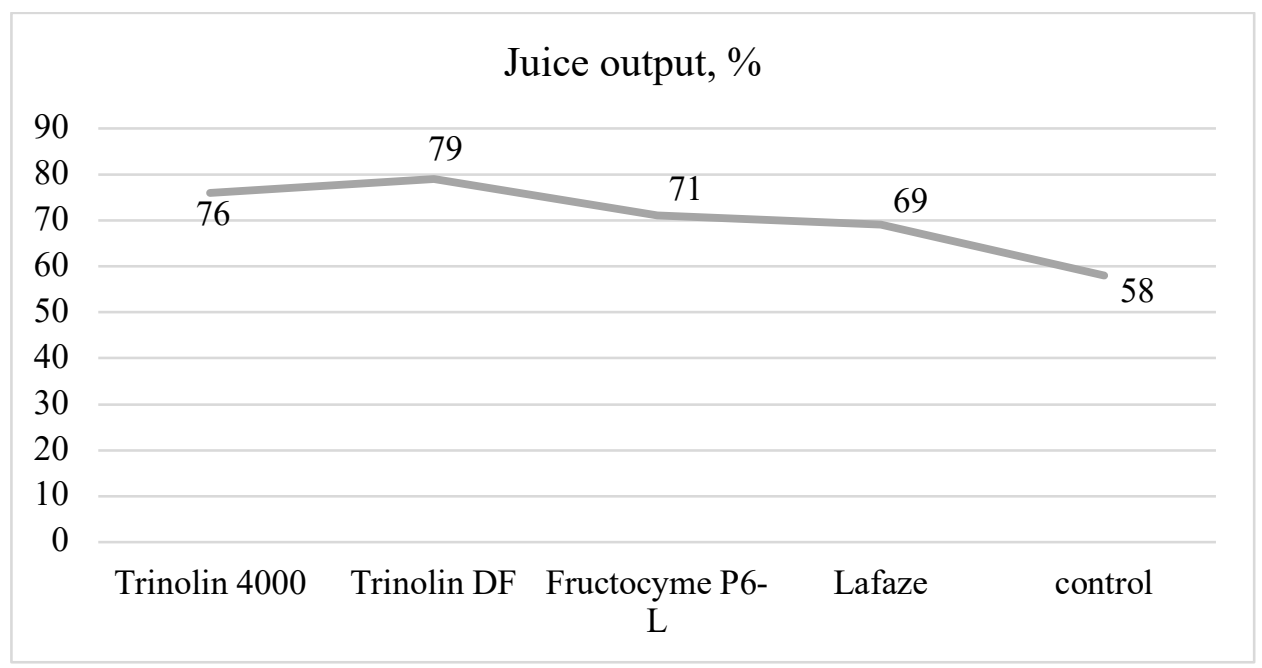

Fig. 1. Effect of APs on the yield of apple juice (Kuban crimson variety)

It was established that the duration of filtration of all experiments conducted in the laboratory indicates a deep splitting of high-molecular components of apple raw materials the destruction of pectins and a sharp drop in viscosity, which increased the yield of gravity juice and biologically active substances. The treatments also had a stabilizing effect on the suspended solids, which made it possible to create good conditions for filtration and clarification of samples $[13,14,15]$. To determine the effectiveness of the isolation of vitamins and aromatic substances from apple raw materials, the effect of each APs separately was investigated $[14,16]$.

It is proved that the treatment of apple fruits with enzyme preparations (Trinoline 4000, Trinolin DF, Fructocyme P6-L, Lafaze), in addition to the thinning effect, increases the concentration of easily digestible biologically active substances and affects the antioxidant potential (Table 1, 2).

Table 1. The content of biologically active substances in apple juice

\begin{tabular}{|l|c|c|c|}
\hline \multicolumn{1}{|c|}{ Sample name } & $\begin{array}{c}\text { Vitamin } \boldsymbol{C}, \\
\mathrm{mg} / 100 \mathrm{~g}\end{array}$ & $\begin{array}{c}\text { Vitamin } \boldsymbol{P}, \\
\mathrm{mg} / 100 \mathrm{~g}\end{array}$ & Soluble pectin, \% \\
\hline Apple juice (control) & 3.20 & 45.60 & 0.32 \\
\hline $\begin{array}{l}\text { Apple juice with APs } \\
\text { (Trinoline 4000) }\end{array}$ & 4.81 & 68.88 & 0.58 \\
\hline $\begin{array}{l}\text { Apple juice with APs } \\
\text { (Trinolin DF) }\end{array}$ & 4.68 & 72.26 & 0.56 \\
\hline $\begin{array}{l}\text { Apple juice with APs } \\
\text { (Fructocyme P6-L) }\end{array}$ & 5.22 & 76.46 & 0.60 \\
\hline $\begin{array}{l}\text { Apple juice with APs } \\
\text { (Lafaze) }\end{array}$ & 4.62 & 78.24 & 0.56 \\
\hline
\end{tabular}


The accompanying components of the aroma of apple juice are represented by monoterpenes (natural hydrocarbons formed by a combination of two isoprene fragments) and their oxygen derivatives (aldehydes, acids, alcohols), the amount of which is presented in Table $2[16,17]$.

Table 2. Aromatic content in apple juice

\begin{tabular}{|c|c|c|c|c|c|}
\hline \multirow[t]{2}{*}{ Component name } & \multicolumn{5}{|c|}{ Aromatic content in juice, $\mathrm{mg} / \mathrm{dm}^{3}$} \\
\hline & $\begin{array}{c}\text { Control } \\
\text { without } \\
\text { APs }\end{array}$ & $\begin{array}{c}\text { (APs) } \\
\text { Trinoline } \\
4000\end{array}$ & $\begin{array}{c}\text { (APs) } \\
\text { Trinoline } \\
\text { DF }\end{array}$ & $\begin{array}{c}\text { (APs) } \\
\text { Fructocyme } \\
\text { P6-L }\end{array}$ & $\begin{array}{c}\text { (APs) } \\
\text { Lafaze }\end{array}$ \\
\hline Acetaldehyde & 194.60 & 194.00 & 193.55 & 193.89 & 194.20 \\
\hline Diacetyl & 0.72 & 0.82 & 0.70 & 0.78 & 0.69 \\
\hline Limonene & traces & 0.01 & 0.01 & 0.01 & 0.01 \\
\hline 2,3-butylene glycol & 3.62 & 3.71 & 3.52 & 3.94 & 3.30 \\
\hline Acetoin & 0.68 & 0.65 & 0.71 & 0.70 & 0.68 \\
\hline Methyl acetate & 6.00 & 6.54 & 6.22 & 6.99 & 6.02 \\
\hline Ethyl acetate & 30.05 & 38.53 & 39.90 & 41.46 & 38.74 \\
\hline Ethylvaleriate & 0.69 & 0.82 & 0.75 & 0.79 & 0.65 \\
\hline Ethylcaprilate & 21.00 & 30.20 & 32.00 & 35.40 & 27.40 \\
\hline Ethyl butyrate & 5.62 & 5.80 & 5.77 & 5.89 & 5.28 \\
\hline Ethyl lactate & 0.41 & 0.45 & 0.43 & 0.42 & 0.40 \\
\hline 1-propanol & 27.43 & 28.55 & 28.04 & 28.99 & 27.50 \\
\hline 2-propanol & 17.40 & 19.80 & 17.68 & 18.20 & 19.01 \\
\hline Isobutanol & 13.05 & 13.22 & 13.12 & 13.88 & 13.10 \\
\hline 1-butanol & 9.18 & 9.21 & 9.18 & 9.21 & 9.15 \\
\hline Ethanol & 0.35 & 0.35 & 0.35 & 0.34 & 0.34 \\
\hline Methylcaprinath & 3.23 & 3.51 & 3.32 & 3.94 & 3.60 \\
\hline Isoamyl & 37.54 & 38.62 & 37.70 & 38.55 & 37.22 \\
\hline Methanol & 51.70 & 50.24 & 52.11 & 52.55 & 50.16 \\
\hline 1-hexanol & 53.79 & 54,12 & 53.84 & 53.99 & 54.04 \\
\hline Isovalerian & 3.12 & 3.61 & 3.32 & 3.14 & 3.21 \\
\hline Acetic acid & 0.97 & 0.99 & 0.98 & 0.97 & 0.96 \\
\hline Phenyletanol & 0.11 & 0.11 & 0.10 & 0.11 & 0.11 \\
\hline \multicolumn{6}{|l|}{ Total components: } \\
\hline Esters & 53.27 & 53.26 & 53.47 & 55.12 & 53.44 \\
\hline Aldehydes & 196.48 & 195.86 & 195.38 & 198.29 & 196.08 \\
\hline Alcohols & 22.69 & 22.99 & 22.75 & 23.05 & 22.65 \\
\hline Acid & 1.66 & 1.74 & 1.69 & 1.70 & 1.69 \\
\hline Ethanol & 0.35 & 0.35 & 0.35 & 0.34 & 0.34 \\
\hline Methanol & 51.70 & 50.24 & 52.11 & 52.55 & 50.16 \\
\hline Altogether & 538.54 & 549.46 & 547.57 & 555.65 & 545.38 \\
\hline
\end{tabular}

An important role 2.3-butylene glycol plays in creating a taste-aromatic perception and is a delicate fruit shade with light almond notes, giving the juice a harmonious apple taste. The brightness of the aroma of fruit juice depends significantly on the concentration and composition of volatile acids. In the studied samples, $3.1-3.6 \mathrm{mg} / \mathrm{dm}^{3}$ of isovaleric acid was found, which gives a floral-fruit tint. [18, 19, 20].

Also in giving a floral and fruity aroma involved higher alcohols (1-propanol), the highest content of which in the sample processed with the enzyme preparation Fructocyme P6-L. In 
large quantities, 1-hexanol (which has a floral tinge in flavor) is found in a juice sample obtained using the enzyme Trinoline 4000.

Analysis of the chemical composition of the obtained hydrolysates proves that preliminary mechanical processing and subsequent enzymatic hydrolysis contributes not only to an increase in the content of vitamins and aromatic substances, but also sugars. [20] (table 3).

Table 3. Sugar content in apple juice

\begin{tabular}{|l|c|c|c|c|}
\hline \multicolumn{2}{|c|}{ Sample name } & \multicolumn{4}{|c|}{ Content, $\mathrm{mg} / 100 \mathrm{~g}$} \\
\cline { 2 - 5 } & glucose & fructose & saccharose & total \\
\hline Apple juice (control) & 4.70 & 5.50 & 0.72 & 10.92 \\
\hline $\begin{array}{l}\text { Apple juice with APs } \\
\text { (Trinoline 4000) }\end{array}$ & 5.44 & 5.56 & 0.84 & 11.84 \\
\hline $\begin{array}{l}\text { Apple juice with APs } \\
\text { (Trinolin DF) }\end{array}$ & 5.52 & 5.62 & 0.92 & 11.06 \\
\hline $\begin{array}{l}\text { Apple juice with APs } \\
\text { (Fructocyme P6-L) }\end{array}$ & 5.84 & 5.58 & 0.94 & 12.36 \\
\hline $\begin{array}{l}\text { Apple juice with APs } \\
\text { (Lafaze) }\end{array}$ & 4.68 & 5.54 & 0.92 & 11.14 \\
\hline
\end{tabular}

In samples of apple juice processed with enzyme preparations, a decrease in starch and fiber and an increase in glucose and sucrose were noted.

\section{Conclusion}

The results of the studies allow us to isolate enzyme preparations Trenolin DF, Trenolin 4000, Fructocyme P6-L, providing an increase in the yield of juice from the fruits of apples (Variety Kuban crimson). Analysis of the laboratory data shows a significant increase in soluble pectin, vitamins $\boldsymbol{C}, \boldsymbol{P}$ and aromatic substances after the use of the enzyme preparation Fructocyme P6-L. All studies allow us to recommend enzyme preparations: Trenolin DF, Trenolin 4000 and Fructocyme P6-L to optimize biotechnological processes in the production of apple juice at enterprises, by reducing the time of its production, increasing yield and improving the quality of the finished product.

\section{References}

1. T. Prichko, E. Ulyanovskaya, N. Droficheva, BIO Web Conf., 25, 02019 (2020) https://doi.org/10.1051/bioconf/20202502019

2. I. Pankina, E. Belokurova, Sc. Jour. of ITMO. Series "Processes and devices of food production", 1, 36-41 (2017) https://doi.org/10.17586/2310-1164-2017-10-1-36-41

3. N. Droficheva, Fruit Growing and Viticulture of South Russia, 64(4), 323-333 (2020) https://doi.org/10.30679/2219-5335-2020-4-64-323-333

4. A. Belén Días, O. Alvarado, I. d'Ory, I. Caro, A. Blandino, Food Bioprod. Proc., 91(4), 580-586 (2013) https://doi.org/10.1016/j.fbp.2013.01.007

5. S. Zhang, H. Chingyuan, G. Yurong, W. Xiaoyu, M. Yonghong, J. Funct. Foods, 76, 104294 (2021) https://doi.org/10.1016/i.jff.2020.104294

6. L. Changjian, J. Jian, X. Yunfei, Y. Hang, G. Yahui, LWT, 147, 111562 (2021) https://doi.org/10.1016/j.lwt.2021.111562

7. N. Potryasov, K. Hakobyan, A. Ponomarenko, Young Scientist, 4(63), 242-244 (2013)

8. A. Wikiera, M. Mika, M. Grabacka, Food Hydrocoll., 44, 151-161 (2015) https://doi.org/10.1016/j.foodhyd.2014.09.018 
9. I. Calvete-Torre, N. Munoz-Almagro, M.T. Pacheco, M.J. Anton, E. Dapena, L. Ruiz, A. Margolles, M. Villamiel, E.J. Moreno, Carbohydr. Polym., 264, 117980 (2021) https://doi.org/10.1016/j.carbpol.2021.117980

10. Z. Lu, F. Ye, G. Zhou, R. Gao, D. Qin, G. Zhao, Food Chem., 330, 127325 (2020) https://doi.org/10.1016/j.foodchem.2020.127325

11. R. Osuga, S. Koide, M. Sakurai, T. Orikasa, M. Uemura, Food Chem., 126, 108014 (2021) https://doi.org/10.1016/j.foodcont.2021.108014

12. M.R. Anna, T.I. Ana, S.T. Laura, M.B. Olga, LWT - Food Sci. Technol., 141, 110926 (2021) https://doi.org/10.1016/j.lwt.2021.110926

13. Y. Wu, S. Li, Y. Tao, D. Li, Y. Han, P.L. Show, G. Wen, J. Zhou, Food Chem., 348, 129083 (2021) https://doi.org/10.1016/j.foodchem.2021.129083

14. S.P. Verma, B. Sarkar, Food Bioprod. Process., 94 147-157 (2015) https://doi.org/10.1016/j.fbp.2015.03.002

15. C. Li, S. Yuan, Y. Xie, Y. Guo, Y. Cheng, H. Yu, H. Qian, W. Yao, Food Chem., 357, 129842 (2021) https://doi.org/10.1016/j.foodchem.2021.129842

16. M. Persic, M. Mikulic-Petkovsek, A. Slatnar, R. Veberic, LWT - Food Sci. Technol., 82, 23-31 (2017) https://doi.org/10.1016/j.lwt.2017.04.017

17. J. Prajapati, P. Dudhagara, K. Patel, Biocatal. Agric. Biotechnol., 35, 102063 (2021) https://doi.org/10.1016/j.bcab.2021.102063

18. I. Ilyina, T. Prichko, N. Droficheva, I. Machneva, S. Gorlov, M. Lukyanenko, Technologies for the production of healthy food products from plant raw materials, 315 (OOO Prosvechenie Ug, Krasnodar, 2018)

19. S.S. Hassan, G.A. Williams, A.K. Jaiswal, Cur. Res. Food Sci., 3, 243-255 (2020) https://doi.org/10.1016/j.crfs.2020.09.003

20. A.E. Illera, M.T. Sanz, S. Beltran, R. Melgosa, A.G. Solaesa, M.O. Ruiz, J. Food Eng., 221, 141-150 (2018) https://doi.org/10.1016/j.jfoodeng.2017.10.017 